\title{
Nematodes associated with five fruit trees in the state of Amapá, Brazil
}

\author{
Nematoides associados a cinco fruteiras no estado do Amapá, Brasil
}

Rodrigo Souza Santos ${ }^{I}$ Paulo Roberto Pala Martinelli ${ }^{I I}$

- NOTE -

ABSTRACT

The aim of this study was to conduct a survey on nematodes associated with five cultivated fruit trees growing in the Agroforestry System (AFS) of the municipality of Oiapoque, Amapá, Brazil. Rhizosphere samples were collected from three points at the base of murici (Byrsonima sp.), soursop (Annona muricata), сирuaçu (Theobroma grandiflorum), passion fruit (Passiflora sp.) and peach palm (Bactris gasipaes) trees. Four species of phytonematodes were identified, namely Pratylenchus brachyurus, Helicotylenchus dihystera, Mesocriconema xenoplax and Rotylenchulus reniformis. The most prevalent and abundant species was $\boldsymbol{R}$. reniformis, which was found in the rhizospheres of passion fruit, cupuaçu, soursop, and peach palm. The first record in Brazil of the nematode P. brachyurus, found in the roots of murici is reported here, and all of the nematode species identified here are the first records for fruit trees in the state of Amapá.

Key words: phytosanitary, fruit production, nematode fauna, pathogens.

\section{RESUMO}

Este estudo teve como objetivo o levantamento de nematoides, associados a cinco fruteiras cultivadas em Sistema Agroflorestal (SAF), no municipio de Oiapoque, AP. Amostras da rizosfera foram coletadas em três pontos, na base de plantas de murici (Byrsonima sp.), graviola (Annona muricata), cupuaçu (Theobroma grandiflorum), maracujá (Passiflora sp.) e pupunha (Bactris gasipaes). Foram constatadas quatro espécies de fitonematoides: Pratylenchus brachyurus, Helicotylenchus dihystera, Mesocriconema xenoplax e Rotylenchulus reniformis. A espécie mais prevalente e abundante foi $\boldsymbol{R}$. reniformis, encontrado na rizosfera de maracujá, cupuaçu, graviola e pupunha. Foi relatado o primeiro registro de $\boldsymbol{P}$. brachyurus em raízes de muricizeiro no Brasil e todas as espécies encontradas configuram-se como primeiros registros de fitonematoides em fruteiras no estado do Amapá.

Palavras-chave: fitossanidade, fruticultura, nematofauna, patógenos.

Murici (Byrsonima [L.] Rich.), soursop (Annona muricata L.), cupuaçu (Theobroma grandiflorum (Willd. ex Spreng. K. Schum.), passion fruit (Passiflora sp.) and peach palm (Bactris gasipaes Kunth) are important crops in northern Brazil, and they are also commonly grown alongside forest species in many Agroforestry Systems (AFSs) reported throughout the rainforests of Brazil (VIEIRA et al., 2007; ANDRADE NETO et al., 2011).

Nematodes are a major phytosanitary problem of the root systems of these crops (DIASARIEIRA et al., 2010; FERRAZ et al., 2010). These pathogens are often overlooked, or their impacts are attributed to some other factor, such as poor nutrition, improper crop management or lack of water (TIMMER et al., 2003).

Many of the fruit tree species commonly used in Brazil's AFSs are known to be phytonematode hosts. PAES et al. (2012) were the first to report Meloidogyne enterolobii Yang and Eisenback in the roots of muricizeiro (Byrsonima cydoniifolia A. Juss.) in the state of Mato Grosso. SILVEIRA et al. (2008) identified six species of phytonematodes in the rhizosphere of soursop plants in the south

IEmbrapa Acre, BR 364, Km 14, CP 321, 69900-970, Rio Branco, AC, Brasil. E-mail: rodrigo.s.santos@embrapa.br. Corresponding author.

IIInstituto Taquaritinguense de Ensino Superior (ITES), Taquaritinga, SP, Brasil. 
of Bahia. OLIVEIRA JÚNIOR et al. (2013) found Helicotylenchus sp. in the soil and roots, and Rotylenchulus reniformis Linford and Oliveira, only in the soil, of samples collected from cupuaçu plants in northern Minas Gerais, and SILVA et al. (2005) observed Tylenchus sp. in the same plant in the state of Amapá. The nematodes Helicotylenchus sp., Tylenchus sp., Ditylenchus sp., Pratylenchus sp., Criconemella spp., Boleodurus sp. and Meloidogyne sp. have all been found in peach palm crops in Costa Rica (ARROYO et al., 2004), although not yet in Brazil.

Information about the nematode fauna associated with crops in Brazil is still limited, with existing research mainly concentrated in northern Brazil. As such, the primary goal of the present study was to conduct a survey of the nematodes inhabiting the rhizospheres of five fruit tree species - murici, soursop, cupuaçu, peach palm and passion fruit.

The survey was conducted in an AFS covering an area of approximately $0.5 \mathrm{ha}\left(04^{\circ} 12^{\prime} 80^{\prime \prime} \mathrm{N}\right.$; $04^{\circ} 18^{\prime} 85^{\prime} \mathrm{W}$, at an altitude of $32 \mathrm{~m}$ ), cultivated in an urban garden in the municipality of Oiapoque, Amapá, in September 2010. In addition to the aforementioned five fruit trees, the AFS included coconut (Cocos nucifera L.), guava (Psidium guajava L.), mango (Mangifera indica L.), avocado (Persea americana Mill.), and numerous forest species that were not identified.

The fruit trees of this AFS were planted at different times and thus are of varying ages; however, according to the site owner, all of the plants sampled were approximately four years old at the time of the study, and no pesticides had been applied since the time they were planted.

Soil samples (approximately 500g) and roots (approximately 100g) were collected with a hoe, at three points and at depths of approximately $30 \mathrm{~cm}$, in accordance with procedures described by GOULART (2009). The samples were packed in polythene bags, identified, stored in thermal containers, and then sent to the Nematology Laboratory at the Agrarian and Veterinary Science Faculty (FCAV/UNESP) in Jaboticabal, in the state of São Paulo.

Nematodes were collected from the soil in aliquots of $100 \mathrm{~cm}^{3}$ via centrifugal flotation in a sucrose solution (JENKINS, 1964); whereas, root nematodes were extracted in aliquots of $10 \mathrm{~g}$ using the method proposed by COOLEN \& D'HERDE (1972). Roots were examined for evidence of adult females of the genus Meloidogyne (SOUZA et al. 1999). Species were identified based in the taxonomic key proposed by MAI \& MULLIN (1996).

Four phytonematode species were found in the rhizospheres of fruit tress cultivated in the AFS, consisting of Pratylenchus brachyurus (Godfrey), Helicotylenchus dihystera (Cobb), Mesocriconema xenoplax (Raski) and R. reniformis (Table 1). Helicotylenchus dihystera had the highest abundance in samples from a single host plant, but $\boldsymbol{R}$. reniformis was the most abundant nematode in the general area (Table 1).

The migratory endoparasitic species $\boldsymbol{P}$. brachyurus was identified from the muricizeiro plant samples analyzed (Table 1). PAES et al. (2012) observed galls of the nematode $M$. enterolobii in the roots of Byrsonima cydoniifolia in the state of Mato Grosso, and Meloidogyne incognita (Kofoid and White) (PONTE et al., 1975), Aorolaimus sp., Pratylenchus sp. (HUANG et al., 1982) and Aorolaimus holdemani (Sher) (BITTENCOURT \& HUANG, 1986) have all been found in Byrsonima crassifolia Kunth. A species of ringed nematode in the genus Criconemoides was also reported to be associated with Byrsonima sp. (HUANG et al., 1976). Pathogenicity tests are needed to confirm the association of $\boldsymbol{P}$. brachyurus with the muricizeiro species but it is tentatively the first report of this nematode occurring in the roots of this plant in Brazil.

With respect to the soursop samples, R. reniformis was found only in the soil and no individual was observed in the radicular system

Table 1 - Species and number of phytonematodes found in the rhizospheres $\left(100 \mathrm{~cm}^{3}\right.$ of soil and $10 \mathrm{~g}$ of roots) of five fruit tree species cultivated in an Agroforestry System (AFS) in the municipality of Oiapoque, Amapá, Brazil.

\begin{tabular}{|c|c|c|c|c|c|c|c|c|c|c|}
\hline \multirow{2}{*}{ Phytonematode species } & \multicolumn{2}{|c|}{--------Murici-------- } & \multicolumn{2}{|c|}{-----Cupuaçu------- } & \multicolumn{2}{|c|}{----Passion fruit---- } & \multicolumn{2}{|c|}{-----Peach palm------ } & \multicolumn{2}{|c|}{--------Soursop----- } \\
\hline & Soil & Root & Soil & Root & Soil & Root & Soil & Root & Soil & Root \\
\hline Rotylenchulus reniformis & - & - & 30 & - & 220 & - & 10 & - & 320 & - \\
\hline Pratylenchus brachyurus & 100 & 50 & 10 & - & - & - & - & - & - & - \\
\hline Helicotylenchus dihystera & - & - & - & - & 30 & - & 340 & - & - & - \\
\hline Mesocriconema xenoplax & - & - & - & - & 10 & - & - & - & - & - \\
\hline
\end{tabular}


(Table 1). In their study of the nematodes linked to soursop in the south of Bahia, SILVEIRA et al. (2008) identified Aphelenchoides sp., Aphelenchus sp., Helicotylenchus sp., Mesocriconema sp., Tylenchus sp., Rotylenchus sp. and Rotylenchulus sp., with the last found only in the soil. As such, despite $\boldsymbol{R}$. reniformis being found in the soil collected from the soursop rhizosphere, it cannot be confirmed as a host plant of this species given that this nematode is a sedentary semi-endoparasite (FORTUNER, 1987), which may be found in the radicular system of these plants. Moreover, as $\boldsymbol{R}$. reniformis has a wide range of host plants, its occurrence in the AFS could be due to the presence of other types of vegetation in the area. Furthermore, as the trees that were sampled were surrounded by grass, and because many members of this tree family generate nematicidic compounds in the roots (GARDIANO et al., 2012), it should not be ruled out that $R$. reniformis is associated with other fruit tree or forest species growing in the AFS.

Among the cupuaçu plants, P. brachyurus and $\boldsymbol{R}$. reniformis were found only in the soil, and at low population densities (Table 1). OLIVEIRA JÚNIOR et al. (2013) found Helicotylenchus sp. in the soil and roots, and $\boldsymbol{R}$. reniformis only in the soil of samples collected from cupuaçu plants in Minas Gerais. It is therefore likely that cupuaçu plants are not hosts of $\boldsymbol{R}$. reniformis, given that the results of our study corroborated with the findings of OLIVEIRA JÚNIOR et al. (2013) for this nematode.

Rotylenchulus reniformis and $\boldsymbol{H}$. dihystera were found only in the soil samples of peach palm, with the latter species exhibiting the highest population density recorded in this study (Table 1). In a survey conducted in the municipality of Porto Grande, Amapá; however, SILVA et al. (2005) did not find nematodes in the soil samples collected from peach palm rhizosphere. In this survey, carried out in the municipality of Oiapoque, it was observed that there were nematodes associated with the peach palm plant rhizosphere but none found in the roots of the plants. Although there are no records of nematodes causing damage to peach palm in Brazil. According to KRZYZANOWSKI (2000), B. gasipaes is not a preferred host of nematodes, because its roots produce exudates that repel them, but $\boldsymbol{H}$. dihystera is an ectoparasitic species (GUZMÁN-PIEDRAHITA, 2011) and thus association with B. gasipaes cannot be discounted.

The nematodes $\boldsymbol{R}$. reniformis, $\boldsymbol{H}$. dihystera and M. xenoplax were identified from the passion fruit rhizosphere samples (Table 1). Yellow passion fruit productivity is low in Brazil, mostly due to diseases caused by phytonematodes, especially those of the root-knot nematodes Meloidogyne spp. and $\boldsymbol{R}$. reniformis (JUNQUEIRA et al., 1999). Previous research has confirmed that the root-knot nematodes M. incognita, Meloidogyne javanica (Treub) and Meloidogyne arenaria (Neal), and the reniform nematode, $\boldsymbol{R}$. reniformis, are the main nematode species driving economic losses in this crop by limiting the productivity and longevity of passion fruit trees (SHARMA et al., 2001; SHARMA et al., 2004). Although the passion fruit tree is known to be a host plant, it was not found $\boldsymbol{R}$. Reniformis in root samples, despite their high abundance in the soil. However, the abiotic factors of the soil environment (temperature, water, texture, air, $\mathrm{pH}$, salinity and organic matter) greatly influenced nematode population size (KIMENJU et al., 2009) and different varieties of passion fruit exhibit varying levels of susceptibility to these phytonematodes (AGUIAR et al., 2010).

Regarding $H$. dihystera and M. xenoplax, the former is considered an ectoparasite (GUZMÁNPIEDRAHITA, 2011); whereas, the latter, although generally described as an ectoparasite as well, has also been found in damaged roots (SHER, 1959; WESTCOTT \& HUSSEY, 1992). The hypothesis that passion fruit, maybe a host plant of these species, cannot be ruled out.

Rotylenchulus reniformis was found in the rhizospheres of four out of the five fruit trees analyzed (Table 1). This species is considered cosmopolitan and widely disseminated throughout the subtropics and tropics (NOE, 2007), and has been reported in association with more than 140 plant species encompassing at least 115 genera from 46 botanical families. Among this wide range of hosts, 57 are commercially important crops (CAMPOS et al., 2002). Thus, although this species was found only in the soil samples, it could be associated with other plants growing in the AFS.

It is common for fruit trees to be grown in AFSs in the Amazon by small-scale farmers and land holders for commercial and livelihood purposes (VIEIRA et al., 2007). However, fruit trees planted in the AFS often lack phytosanitary certification, contributing to the dissemination of phytonematodes among regions, municipalities and states. Given the perennial nature and the length of time in which plants growing in an AFS remain in close proximity and the fact that most phytonematode species have a range of host plants (FERRAZ et al., 2010) and thus the high likelihood of their dissemination throughout the AFS - it is recommended that fruit trees intended 
for planting in an AFS meet phytosanitary standards (PEREIRA et al., 1996).

In this study, it was identified a number of potentially harmful nematode species in the rhizospheres of the plants selected for analysis. Although no noticeable damage was observed in the plant samples, careful monitoring of these nematodes is required, especially in the large fruit-tree plantations in the state of Amapá, given that all the nematode species found are polyphagous phytoparasites.

Rotylenchulus reniformis was the most abundant and prevalent nematode found in the rhizospheres of passion fruit, cupuaçu, soursop and peach palm cultivated in the AFS. Passion fruit trees had the largest number of species of phytonematodes associated with their rhizospheres. Pratylenchus brachyurus was found in the roots of murici in the state of Amapá, constituted the first record for the occurrence of this nematode in murici in Brazil.

All of the nematode species observed are phytoparasites and to our knowledge, this is the first time they have been reported to occur in fruit trees in the state of Amapá.

\section{REFERENCES}

AGUIAR, A.V.M. et al. Use of species Passiflora spp. as rootstocks in the control of diseases of passion fruit. Agropecuária Científica no Semi-Árido, v.6, n.4, p.17-22, 2010.

ANDRADE NETO, R.C. et al. Diagnóstico da potencialidade da fruticultura no Acre. Rio Branco: Embrapa Acre, 2011. 36p. (Documento, 125).

ARROYO, C. et al. Dinámica poblacional de nematodos fitoparásitos en pejibaye (Bactris gasipaes K.) para palmito. Agronomia Mesoamericana, v.15, n.1, p.53-59, 2004. Available from: <http://dx.doi.org/10.15517/am.v15i1.11929>. Accessed: Apr. 06, 2016. doi: 10.15517/am.v15i1.11929.

BITTENCOURT, C.; HUANG, C.S. Brazilian Peltamigratus Sher, 1964 (Nematoda; Hoplolaimidae) with description of six new species. Revue de Nematologie, v.9, p.3-24, 1986.

CAMPOS, V.P. et al. Manejo de doenças causadas por nematoides em frutíferas. In: ZAMBOLIM, L. (Ed.). Manejo integrado: fruteiras tropicais, doenças e pragas. Viçosa: Suprema Gráfica e Editora, 2002. p.185-238.

COOLEN, W.A.; D'HERDE, C.J.D. A method for the quantitative extraction of nematodes from plant tissue culture. Ghent, Belgium: State Agriculture Research Centre, 1972. 77p.

DIAS-ARIEIRA, C.R. et al. Plant parasitic nematodes associated with fruit crops in the Northwest of Paraná, Brazil. Revista Brasileira de Fruticultura, v.32, n.4, p.1064-1071, 2010. Available from: <http://dx.doi.org/10.1590/S010029452010005000119>. Accessed: Apr. 06, 2016. doi: 10.1590/ S0100-29452010005000119.
FERRAZ, S. et al. Manejo sustentável de fitonematoides. Viçosa: UFV, 2010. 304p.

FORTUNER, R. A reappraisal of the Tylenchida (Nemata). 8. The family Hoplolaimidae Filip'ev, 1934. Revue de Nématologie, v.10, p.219-232, 1987.

GARDIANO, C.G. et al. Hospitability of soil improving crops to Rotylenchulus reniformis Linford and Oliveira (1940). Arquivos do Instituto Biológico, v.79, n.2, p.313-317, 2012. Available from: <http://dx.doi.org/10.1590/S1808-16572012000200025>. Accessed: Apr. 06, 2016. doi: 0.1590/S1808-16572012000200025.

GOULART, A.M.C. Coleta de amostras para análise de nematoides: recomendações gerais. Planaltina, DF: Embrapa Cerrados, 2009. 31p. (Embrapa Cerrados, Documento, 255).

GUZMÁN-PEDRAHITA, O.A. Importance of spiral nematodes, Helicotylenchus multicinctus (Cobb) Golden y H. dihystera (Cobb) Sher, on banana and plantain. Agronomia, v.19, n.2. p.19-32, 2011.

HUANG, C.S. et al. Nematóides de estilete do cerrado virgem no Brasil Central. In: CONGRESSO BRASILEIRO DE FITOPATOLOGIA, 9., 1976. Campinas, SP. Resumos... Campinas, SP: Sociedade Brasileira de Fitopatologia, 1976. p.30.

HUANG, C.S. et al. Nematóides fitoparasitos encontrados na Ilha de São Luiz e município de Rosário do Estado do Maranhão. In: REUNIÃO BRASILEIRA DE NEMATOLOGIA, 6., 182, Fortaleza, CE. Resumos... Fortaleza, CE: Sociedade Brasileira de Nematologia/UFC, 1982. p.39.

JENKINS, W.R. A rapid centrifugal-flotation technique for separating nematodes from soil. Plant Disease Reporter, v.48, n.4, p.692, 1964.

KIMENJU, J.W. et al. Nematode community structure as influenced by land use and intensity of cultivation. Tropical and Subtropical Agroecossystems, v.11, p.353-360, 2009.

KRZYZANOWSKI, A.A. et al. Hospedabilidade da pupunha (Bactris gasipaes) frente as raças de Meloidogyne incognita, M. paranaensis e M. javanica. Nematologia Brasileira, v.24, n.1, p.120-122, 2000.

MAI, W.F.; MULLIN, P.G. Plant parasitic nematodes: a pictorial key to genera. 5.ed. Ithaca: Cornell University, 1996. 288p.

NOE, J.P. Plant-parasitic nematodes. In: TRIGIANO, R.N.et al. Plant pathology: concepts and laboratory exercises. 2.ed. New York: CRC, 2007. 576p.

OLIVEIRA JUNIOR, J.L. et al. Levantamento populacional de nematoides no consórcio de banana 'Prata-Anã' com fruteiras no Norte de Minas. In: SEMINÁRIO DE INICIAÇÃO CIENTÍFICA E TECNOLÓGICA, 10., Belo Horizonte, MG. Resumos... Belo Horizonte: EPAMIG, 2013. 5p.

PAES, V. DOS S. et al. Ocorrência de Meloidogyne enterolobii em muricizeiro (Byrsonima cydoniifolia). Tropical Plant Pathology, v.37, n.3, p.205-219, 2012. Available from: <http:// dx.doi.org/10.1590/S1982-56762012000300009>. Accessed: Apr. 06, 2016. doi: 10.1590/S1982-56762012000300009.

PEREIRA, A.V. et al. Seringueira em sistemas agroflorestais. Planaltina, DF: Embrapa Cerrados, 1996. 42p. (Embrapa Cerrados, Documento, 63). 
PONTE, J. J. et al. Segunda lista de hospedeiros de Meloidogyne do Distrito Federal (Brasil). Fitopatologia Brasileira, v.1, p.105$109,1975$.

SHARMA, R.D. et al. Behavior of sweet passion fruit (Passiflora alata) to root-knot nematodes. Nematologia Brasileira, v.28, n.1, p.97-100, 2004.

SHARMA, R.D. et al. Reaction of passionfruit genotypes to the reniform nematode, Rotylenchulus reniformis. Nematologia Brasileira, v.25, n.2, p.211-215, 2001.

SHER, S.A. A disease of carnations caused by the nematode Criconemoides xenoplax. Phytopathology, v.49, n.11, p.761-763, 1959.

SILVA, R.A. et al. Levantamento preliminar de fitonematóides em culturas agrícolas no estado do Amapá. In: REUNIÃO ANUAL DO INSTITUTO BIOLÓGICO, 18., 2005, São Paulo, SP. Resumos... São Paulo: Instituto Biológico, 2005. p.79.

SILVEIRA, A. et al. Phytonematodes associated to soursop tree (Annona muricata) in the South of Bahia. Revista Brasileira de
Fruticultura, v.30, n.3, p.838-840, 2008. Available from: <http:// dx.doi.org/10.1590/S0100-29452008000300048>. Accessed: Apr. 06, 2016. doi: 10.1590/S0100-29452008000300048.

SOUZA, J.T. de. et al. Nematodes associated with fruit crops in some brazilian states. Ciência e Agrotecnologia, v.23, n.2, p.353-357, 1999.

TIMMER, L.W. et al. Diseases of citrus. In: PLOETZ, R.C. (Ed.) Diseases of tropical fruit crops. London: $\mathrm{CAB}$ International, 2003. p.197-226.

VIEIRA, T.A. et al. Agroforestry systems in areas of smallholder agriculture in Igarapé-Açu, Pará: floristic characterization, implantation and management. Acta Amazonica, v.37, n.4, p.549558, 2007. Available from: <http://dx.doi.org/10.1590/S004459672007000400010>. Accessed: Apr. 06, 2016. doi: 10.1590/ S0044-59672007000400010.

WESTCOTT, S.W.; HUSSEY, R.S. Feeding behavior of Criconemella xenoplax in monoxenic cultures. Phytopathology, v.82, p.936-940, 1992. 